\title{
The Impact of Owner and Firm Characteristics on External Capital Acquisition at Start-up: Empirical Evidences from Swedish Data
}

\author{
Saeid Abbasian ${ }^{1} \&$ Darush Yazdanfar ${ }^{2}$ \\ ${ }^{1}$ Department of Social Science, Unit of Tourism \& ETOUR, Mid Sweden University, Östersund, Sweden \\ ${ }^{2}$ Department of Social Science, Unit of Business Administration, Mid Sweden University, Östersund, Sweden \\ Correspondence: Saeid Abbasian, Department of Social Science, Unit of Tourism \& ETOUR, Mid Sweden \\ University, 83125 Östersund, Sweden. Tel: 46-63-165-373. E-mail: saeid.abbasian@miun.se
}

Received: September 21, 2012

Accepted: October 18, 2012

Online Published: November 11, 2012

doi:10.5539/ibr.v5n12p19

URL: http://dx.doi.org/10.5539/ibr.v5n12p19

\begin{abstract}
The present study investigates whether owner and firm characteristics influence the use of external financing sources among Swedish small-owned firms at start-up stage. Several methods, including multinomial binary logistic regression have been employed to analyse a unique and comprehensive firm-level database, consisting of 2,814 firms gathered through interviews. The results show that three variables, i.e., loans from family members and friends, bank debt and funding from angel investors, are significant in distinguishing between Swedish native and immigrant-owned firms in the acquisition of financial sources in start-up. In addition, immigrant-owned firms tend to relay more on informal financial sources e.g. loan from family member, friends and angel investors, and less on bank loan. Furthermore, whereas, ethnicity influences the change of all these four variables significantly, gender merely affects loans from family members. Other variables, such as the owners' age, prior experience in business, education, having an additional job beside one's own business, the amount of personal start-up capital and firm size, as well as legal form and industry affiliation are partly important to explain the acquisition use of external capital at start-up stage.
\end{abstract}

Keywords: ethnicity, gender, start-up capital, small business, Sweden

\section{Introduction}

New businesses formed by Immigrants have a positive impact on their general, social and economic integration into Western societies (Kloosterman, 2003; Smart, 2003; Srinivasan, 1995; Werbner, 1990). The challenge to finance the new business, however, has been assumed to be one of the main obstacles faced by immigrant- and ethnic minority-owned firms at startup stage (Bruder et al., 2011; Irwin \& Scott, 2010). It is supposed that many immigrants have difficulties with the financing of start-up capital (Ram et al., 2008; Ramangalahy et al., 2002; Smallbone et al., 2005), and face harder difficulties than their native-born counterparts (Lo et al., 2002). Immigrants, in general, also have less income than native-born inhabitants, as a result of which they have less financial resources (Cobb-Clarck \& Hildebrand, 2002). To solve these problems they use ethnic informal financing sources rather than formal sources such as banks and credit institutions (Huck et al., 1999; Kushnirovich \& Heilbrunn, 2008; Raijman \& Tienda, 2003; Ram et al., 2003).

Women's entrepreneurship, in general, is important for Western societies (Brush et al., 2006; Verheul et al., 2004; Guiso \& Rustichini 2011). Native-born female entrepreneurs are exposed to more rejection by banks, and they pay more interest than their male counterparts (Verheul et al., 2004; Muravyev et al., 2007). On the other hand, they have significantly more likelihood than immigrants to obtain bank loans (see, for example, Blanchflower et al., 2003). Women often start businesses with less resources than men (Carter \& Allen 1997) and they often appeal to external sources of capital less than men (Brophy, 1989; Brush, 1992), mostly as a result of concerns about being refused financing (Marlow \& Carter, 2006). Consequently, they rely on informal sources of capital such as friends and family. The situation is likely to become even worse for female immigrants as they have less access to financial resources than both groups (Davidson et al., 2010; Essers \& Benschop, 2007; Maltay et al., 2011; Schrover et al., 2007).

The question, however, is why native female small business owners and their ethnic counterparts face financial constraints by banks to a greater extent than native male owners. In part of previous studies, researchers looked 
for explanations for such treatments by banks, by focusing on the characteristics of owners and firms.

Characteristics of owners (mainly gender and ethnicity) have been examined in explanation of differences between small business owners with regard to access to external start-up capital. Another significant variable, in addition to ethnicity and gender, examined by Irwin and Scott (2010), has been educational level. Other contributing variables, as well as education, suggested by Osili and Paulson (2004), are income and geographic location, whilst Kushnirovich and Heilbrunn (2008) emphasized access to own start-up capital. Basu and Parker (2001) suggest a lack of adequate collateral and security as an explanation for the debt capital constraints of Asian and East African entrepreneurs in the UK.

Moreover, differences between male and female entrepreneurs, with regard to access to external start-up capital, have been explained by evidence of the characteristics of owners. Men, for example, are more associated with successful entrepreneurship than women (Fay \& Williams, 1993). Research has also focused on the characteristics and difference in behaviour to describe the gender gap in attitudes to external capital acquisition (Huang \& Kisgen, 2008; Robb \& Wolken, 2002). Other studies show that male and female entrepreneurs differ in previous experiences and professions, education, and prior entrepreneurial experiences (Brush, 1992; Fischer et al., 1993; Verheul \& Thurik, 2001).

Characteristics of firms have dealt with, among others, firm size, the legal form and industry affiliation, and whether they play role in differences in access to start-up capital among business owners, across the gender and ethnicity boundaries. Businesses owned by women and immigrants are generally smaller and younger than male-owned businesses (Coleman, 1998; Devine, 1994; Hussain et al., 2008). Studies by Blanchflower et al., (2003) and Cavalluzzo et al. (2002) show that characteristics of firms (age of the firm, size, sale, previous bankruptcy and creditworthiness, location of firms, industry affiliation, etc) might partly play a role in favouring male and female native entrepreneurs against female and male minority entrepreneurs, and favouring male native entrepreneurs against female native entrepreneurs. Businesses owned by women and immigrants are also highly concentrated in the service sector (Hedberg, 2009; Kalleberg \& Leicht, 1991). Also legal form of the business has been used as analysing factor for differences (Bruder et al., 2011; Papadaki \& Chami, 2002).

The purpose of this paper is to examine whether ethnicity, gender and other characteristics of owners and firms can explain differences of financing sources, used by Swedish small native and immigrant-owned firms at the start-up stage.

The remainder of the study is organized as follows: section 2 presents hypotheses, definitions and classifications of financing sources, data sources and method, section 3 provides an overview of the data sources and methods used in the study; section 4 discusses the empirical results and findings whilst section 5 concludes the study.

\section{Hypotheses, Definitions and Classifications of Financing Sources, Data Sources and Method}

\subsection{Hypotheses}

The relevant previous studies in combination with data availability have, fundamentally, been the basis of the hypotheses in this study. Unlike many previous studies, the current study uses a larger sample and larger number of independent variables. The first set of hypotheses (2-7) considers the effects of the owners' characteristics on using certain types of funding (value 1) versus does not do that (value 0). The second set of hypotheses (8-11) focuses on the effects of the firms' characteristics on the probability of using certain types of funding (value 1) versus does not do that (value 0 ).

Hypothesis 1: The external financing differs significantly between native-born and immigrant-owned firms at start-up stage.

Hypothesis 2: Owner's ethnic background significantly influences whether they use specific types of external financing sources at start-up stage.

Hypothesis 3: Owner's gender significantly influences whether they use specific types of external financing sources at start-up stage.

Hypothesis 4: Owner's age significantly affects whether they use specific types of external financing sources at start-up stage.

Hypothesis 5: Owner's previous experience before starting business significantly influences whether they use specific types of external financing sources at start-up stage.

Hypothesis 6: Owner's work, beside their own business, significantly influences whether they use specific types of external financing sources at start-up stage. 
Hypothesis 7: Owner's educational level significantly influences whether they use specific types of external financing sources at start-up stage.

Hypothesis 8: Owner's personal start-up capital has a significant effect on whether they use specific types of external financing sources at start-up stage.

Hypothesis 9: Firm size is related significantly to whether its owner uses specific types of external financing sources at start-up stage.

Hypothesis 10: The legal form of the firm is related significantly to whether its owner uses specific types of external financing sources at start-up stage.

Hypothesis 11: A firm's industry affiliation is related significantly to whether its owner uses specific types of external financing sources at start-up stage.

\subsection{Definitions and Classifications}

Small firms finance their activities at start-up by combining different internal, external, formal and informal financial sources. Following Smallbone et al. (2003), funds generated by the owner or firm are classified as internal financing in this study. On the other hand, the external financing is defined here as all other financial funding available to the business owner: (1) informal sources, e.g. loans or gifts from family and friends; (2) formal sources, such as banks, venture capital funding by second partner, and grant-awarding bodies like Swedish state-owned credit agency ALMI; (3) risk capital sources raised by risk capital companies and angel investors; and (4) other financial sources. Finally, the immigrant-owned firms have been defined according to SCB (Statistics Sweden) as firms incorporated and owned by residents born outside of Sweden.

\subsection{Data Sources}

The panel database used in this study was collected by the Swedish Small Business Forum through phone interviews in autumn 2008. The sample covers all available small firms established during 2005-2008 in four regions in south-east Sweden, and consists of 2,814 firms: 2,510 native-; and 304 immigrant-owned active small firms.

\subsection{Method}

Given that the dependent variables are binary variables, to examine the hypotheses formulated above, the multiple binary logistic regression analysis was utilized as the main model in this study. The advantage of this method is that the logistic model is somewhat less challenging in terms of basic normal distributional assumptions, and minimizes the effects of outliers on the results. In addition, the application of the stepwise analysis is opposed to the direct simultaneous entry of all independent variables, and so minimizes the number of explanatory variables selected for analysis and leads to the better results and higher overall Wilke's lambda.

The dependent variable is defined by coding an indicator binary variable, (i.e., a dummy variable) as 1 (used specific types of external financing sources) or 0 (not used). A given change in an explanatory variable will make little difference to the probability of the dependent variable.

The underlining equation in logistic regression analysis is according to following model:

$$
y_{i}^{*}=\alpha_{0}+\beta_{1}(X 1)+\beta_{2}(X 2)+\beta_{3}(X 3)+\beta_{4}(X 4)+\beta_{5}(X 5)+\beta_{6}(X 6)+\beta_{7}(X 7)+\beta_{8}(X 8)++\beta_{9}(X 9)+\varepsilon
$$

where:

$y_{i}^{*}=$ binary variable, if the firm uses a certain type of financing source, $y_{\mathrm{i}}=1$, otherwise it is 0

Based on the results of ANOVA (section 3.3), the dependent variables are: loan from family members, loan from friends, bank loans, and Funding by angel investors.

The independent variables are:

$\mathrm{X} 1$ : Ethnicity

$\mathrm{X} 2$ : Owner's age, natural logarithm

X3: University education

$\mathrm{X} 4$ : Experience of starting up a business before

$\mathrm{X} 5$ : Additional job beside the business

X6: Personal start-up capital, natural logarithm

$\mathrm{X} 7$ : Number of employees as proxy of size, natural logarithm 
X8: Firm Legal form: the less formalized legal form, sole proprietorship, is coded as (1); trading partnerships (2); most formalized legal form limited liability companies (3).

X9: Firm industry affiliation: manufacturing sector with most physical capital coded as (1); construction (2); transport (3); retail and wholesale (4); consulting and related services (5); restaurants (6).

$\varepsilon=$ error term

\section{Empirical Results}

\subsection{Descriptive Analysis}

As a first step, descriptive statistics are used to demonstrate key characteristics of all owners and firms in the study. The variables related to owners are ethnicity, gender, age, experience of starting up a business before, job beside the current business, and university education. The firm characteristic variables are: size i.e. the number of employees; amount of start-up capital; legal form; and industry affiliation, for both native- and immigrant-owned firms (Table 1).

Around 30 per cent of all owners in the sample are female and the remaining 70 per cent male. The proportion of female owners among the immigrant group is somewhat larger than the native counterpart. This small difference is, however, not statistically significant. Similarly, there is no significant difference between the mean age of native and immigrant owned owners $(F=3.37, P=0.07)$, and the average age of business owners is around 42.5 years.

There is also no significant difference between the two groups with regard to whether they had ever started or owned other businesses before. On average, around 35 per cent of the owners have had previous experience of starting a business.

Although roughly 40 per cent of all owners held an additional job beside their own business, there is no statistically significant difference between native owners and their immigrant counterparts regarding this question $(F=2.66, P=10.36)$. In addition, whereas 24.3 per cent of owners had a secondary education, only 15.4 per cent of them had a university education. There is no significant mean difference between native business owners and immigrant owners for educational level $(F=0.7852, P=0.38)$.

Table 1. Mean, standard deviation and number of variables included in pooled sample

\begin{tabular}{|c|c|c|c|c|c|c|c|c|c|c|}
\hline & & Age & $\begin{array}{l}\text { Started } \\
\text { before }\end{array}$ & businesses & $\begin{array}{l}\text { Additio } \\
\text { nal job }\end{array}$ & $\begin{array}{l}\text { University } \\
\text { education }\end{array}$ & $\begin{array}{l}\text { Number of } \\
\text { employees }\end{array}$ & $\begin{array}{l}\text { Start-up } \\
\text { capital }\end{array}$ & $\begin{array}{l}\text { Legal } \\
\text { form }\end{array}$ & $\begin{array}{l}\text { Industry } \\
\text { affiliation }\end{array}$ \\
\hline \multirow[t]{3}{*}{ Native } & Mean & 42.650 & 1.655 & & 1.576 & 1.819 & 1.966 & 3.840 & 20.390 & 3.249 \\
\hline & Std. Deviation & 12.584 & 0.479 & & 0.498 & 0.424 & 2.957 & 2.110 & 16.458 & 1.422 \\
\hline & $\mathrm{N}$ & 2510 & 2510 & & 2510 & 2510 & 2510 & 2510 & 2510 & 2510 \\
\hline \multirow[t]{3}{*}{ Immigrants } & Mean & 41.25 & 1.61 & & 1.63 & 1.80 & 3.24 & 4.00 & 19.91 & 3.44 \\
\hline & Std. Deviation & 11.95 & 0.51 & & 0.50 & 0.43 & 14.01 & 2.00 & 15.79 & 1,62 \\
\hline & $\mathrm{N}$ & 304 & 304 & & 304 & 304 & 304 & 304 & 304 & 304 \\
\hline \multirow[t]{3}{*}{ Total } & Mean & 42.50 & 1.65 & & 1.58 & 1.82 & 2.10 & 3.86 & 20.34 & 3,27 \\
\hline & Std. Deviation & 12.5228 & 0.4823 & & 0.4985 & 0.4240 & 5.3938 & 2.0987 & 16.3851 & 1.4451 \\
\hline & $\mathrm{N}$ & 2814 & 2814 & & 2814 & 2814 & 2814 & 2814 & 2814 & 2814 \\
\hline \multirow[t]{4}{*}{ ANOVA } & $\mathrm{F}$ & 3.3786 & 2.5011 & & 2.6606 & 0.7852 & 15.2834 & 1.4954 & 0.2344 & 4.9584 \\
\hline & Sig. & 0,07 & 0,11 & & 0,10 & 0,38 & 0,00 & 0,22 & 0,63 & 0,03 \\
\hline & Welch test & 0.056 & 0.132 & & 0.104 & 0.379 & 0.617 & 0.114 & 0.204 & 0.045 \\
\hline & Levene Statistic & 0.028 & 0.001 & & 0.005 & 0.139 & 0.100 & 0.000 & 0.039 & 0.000 \\
\hline
\end{tabular}

Levene Statistic: Test of Homogeneity at $0.05 \%$ level; Welch: Robust Tests of Equality of Means between the two groups $0.05 \%$ level.

Moreover, the firms in the sample are micro and young businesses, established between 2005 and 2008. Nevertheless, the size of native and immigrant-owned firms, measured in terms of number of employees, differs significantly $(F$ test $=15.25 ; P=0.000)$. Legally, approximately 70 per cent of all firms are incorporated as sole proprietorships followed by limited liability companies $(22 \%)$, and trading partnerships $(8 \%)$. No significant difference is found between native- and immigrant-owned firms in terms of legal form $(F=0.23 ; P=62.83)$. Around 57 per cent of all firms are classified as service companies, 18 per cent as manufacturing firms, 12 per cent as retail firms, and 13 per cent as other industries, including transport, construction, restaurants, and consulting. There are not significant differences in the mean scores of the native and immigrant respondents 
either $(F=4.95 ; P=2.65)$.

\subsection{The Sources of Start-up Funds by Ethnic Background}

Table 2 presents the descriptive statistics of empirical data by ethnic background, for different external financial sources undertaken at start-up. It demonstrates the percentage of native- and immigrant-owned firms, respectively, who have acquired funding from family members (25-37\%); friends (4-20\%); capital raised by second partner (12-10\%); loan from bank (35-29\%); loan from government agency ALMI- Företagspartner (4-6\%); grant from government (10-14\%); risk capital companies (1-1\%); angel investors $(1-5 \%)$; and other sources (1-2\%), for the external financing of start-up capital. As shown, the use of five funding sources (loans from family members, friends, and bank, plus grants from government and funding by angel investors) are statistically significant by groups at the 5 per cent significance level. However, the small differences concerning use of capital raised by second partner, ALMI and other funding sources are not statistically significant.

Bank loans have been ranked by the majority of firms as the first financing alternative (35\%), then loans from family members as a second financing option (26\%). In contrast, risk capital (1\%) and funding by angel investors $(1 \%)$ have been regarded as the last financing options.

Table 2. The distribution of sources of start-up funds by ethnic background

\begin{tabular}{|c|c|c|c|c|c|}
\hline & & No & Yes & $N$ & Std. Deviation \\
\hline \multirow[t]{3}{*}{ Family members } & Native & $75 \%$ & $25 \%$ & 2,510 & 0.43 \\
\hline & Immigrants & $63 \%$ & $37 \%$ & 304 & 0.48 \\
\hline & Total & $74 \%$ & $26 \%$ & 2,814 & 0.44 \\
\hline \multirow[t]{3}{*}{ Friends } & Native & $96 \%$ & $4 \%$ & 2,510 & 0.19 \\
\hline & Immigrants & $80 \%$ & $20 \%$ & 304 & 0.40 \\
\hline & Total & $94 \%$ & $6 \%$ & 2,814 & 0.23 \\
\hline \multirow[t]{3}{*}{ Partner } & Native & $88 \%$ & $12 \%$ & 2,510 & 0.32 \\
\hline & Immigrants & $90 \%$ & $10 \%$ & 304 & 0.30 \\
\hline & Total & $94 \%$ & $6 \%$ & 2,814 & 0.32 \\
\hline \multirow[t]{3}{*}{ Bank } & Native & $65 \%$ & $35 \%$ & 2,510 & 0.48 \\
\hline & Immigrants & $71 \%$ & $29 \%$ & 304 & 0.45 \\
\hline & Total & $65 \%$ & $35 \%$ & 2,814 & 0.48 \\
\hline \multirow[t]{3}{*}{ Loan from ALMI } & Native & $96 \%$ & $4 \%$ & 2,510 & 0.19 \\
\hline & Immigrants & $94 \%$ & $6 \%$ & 304 & 0.23 \\
\hline & Total & $96 \%$ & $4 \%$ & 2,814 & 0.20 \\
\hline \multirow[t]{3}{*}{ Government grants } & Native & $90 \%$ & $10 \%$ & 2,510 & 0.30 \\
\hline & Immigrants & $86 \%$ & $14 \%$ & 304 & 0.35 \\
\hline & Total & $89 \%$ & $11 \%$ & 2,814 & 0.31 \\
\hline \multirow[t]{3}{*}{ Risk capital companies } & Native & $99 \%$ & $1 \%$ & 2,510 & 0.09 \\
\hline & Immigrants & $99 \%$ & $1 \%$ & 304 & 0.10 \\
\hline & Total & $99 \%$ & $1 \%$ & 2,814 & 0.09 \\
\hline \multirow[t]{3}{*}{ Angel investors } & Native & $99 \%$ & $1 \%$ & 2,510 & 0.10 \\
\hline & Immigrants & $95 \%$ & $5 \%$ & 304 & 0.22 \\
\hline & Total & $99 \%$ & $1 \%$ & 2,814 & 0.12 \\
\hline \multirow[t]{3}{*}{ Other sources } & Native & $98 \%$ & $2 \%$ & 2,510 & 0.14 \\
\hline & Immigrants & $99 \%$ & $1 \%$ & 304 & 0.11 \\
\hline & Total & $98 \%$ & $2 \%$ & 2,814 & 0.14 \\
\hline
\end{tabular}

Table 3 below illustrates the importance of different financing sources used by firms of start-up capital. The results of this analysis confirm, once more, that compared to native-owned firms, a higher proportion of immigrant-owned firms used loans from family members and friends, grants from the government, and funding from angel investors to start their firms. In contrast, native-owned firms relied more on bank loans to obtain funding. 
Table 3. Mean, standard deviation and number of dependent variables

\begin{tabular}{lllllllllll}
\hline National & & $\begin{array}{l}\text { Family } \\
\text { members }\end{array}$ & Friends & Partner & Bank & ALMI & $\begin{array}{l}\text { Government } \\
\text { grants }\end{array}$ & $\begin{array}{l}\text { Risk capital } \\
\text { com. }\end{array}$ & $\begin{array}{l}\text { Angel } \\
\text { investors }\end{array}$ & $\begin{array}{l}\text { Other } \\
\text { sources }\end{array}$ \\
\hline Native & Mean & 1.250 & 1.039 & 1.117 & 1.354 & 1.038 & 1.102 & 1.008 & 1.011 & 1.021 \\
& Std. Deviation & 0.43 & 0.19 & 0.32 & 0.48 & 0.19 & 0.30 & 0.09 & 0.10 & 0.14 \\
& $\mathrm{~N}$ & 2,510 & 2,510 & 2,510 & 2,510 & 2,510 & 2,510 & 2,510 & 2,510 & 2,510 \\
Immigrant & Mean & 1.37 & 1.20 & 1.10 & 1.29 & 1.06 & 1.14 & 1.01 & 1.05 & 1.01 \\
& Std. Deviation & 0.48 & 0.40 & 0.30 & 0.45 & 0.23 & 0.35 & 0.10 & 0.22 & 0.11 \\
& $\mathrm{~N}$ & 304 & 304 & 304 & 304 & 304 & 304 & 304 & 304 & 304 \\
Total & Mean & 1.26 & 1.06 & 1.12 & 1.35 & 1.04 & 1.11 & 1.01 & 1.01 & 1.02 \\
& Std. Deviation & 0.44 & 0.23 & 0.32 & 0.48 & 0.20 & 0.31 & 0.09 & 0.12 & 0.14 \\
& $\mathrm{~N}$ & 2,814 & 2,814 & 2,814 & 2,814 & 2,814 & 2,814 & 2,814 & 2,814 & 2,814 \\
\hline
\end{tabular}

Note: The binary dependent variable is defined as 1 (used specific types of external financing sources) or 0 (not used).

\subsection{Test of the Statistical Significance ANOVA Test}

In this section, the ANOVA and other relevant tests are carried out to examine whether ethnicity variable is statistically significant to explain the differences between external financing of the native and immigrant groups. The results of ANOVA reported in Table 4 indicate that statistically significant differences are found between native and immigrant groups, regarding four financial sources: loans from family members, friends, banks, and angel investors at the 5 per cent level. In contrast, the differences related to other financing sources, namely capital raised by a second partner, government grants, funding from risk capital companies, and other sources, are not statistically significant.

The validity tests of ANOVA, including Welch's test, Levene statistic and Jarque-Bera test (J-B test), indicate the robustness of results relating to loans from family members, friends, banks and angel investors. To make further investigation into the study, a logistic regression has been implemented.

Table 4. ANOVA, Levene and Welch t-test and JB-test of the dependent variables

\begin{tabular}{|c|c|c|c|c|c|c|c|c|c|}
\hline & & $\begin{array}{l}\text { Sum of } \\
\text { squares }\end{array}$ & $\mathrm{df}$ & $\begin{array}{l}\text { Mean } \\
\text { Square }\end{array}$ & $F$ & Sig. & Welch-test & $\begin{array}{l}\text { Levene } \\
\text { statistic }\end{array}$ & $\begin{array}{l}\text { JB } \\
\text { p-value }\end{array}$ \\
\hline \multirow[t]{3}{*}{ Family members } & Between groups & 3.60673 & 1 & 3.60673 & 18.75236 & $0.000 * *$ & 0.000 & 0.000 & 0.000 \\
\hline & Within groups & 540.8453 & 2812 & 0.192335 & & & & & \\
\hline & Total & 544.452 & 2813 & & & & & & \\
\hline \multirow[t]{3}{*}{ Friends } & Between groups & 6.762878 & 1 & 6.762878 & 132.7525 & $0.000 * *$ & 0.000 & 0.000 & 0.000 \\
\hline & Within groups & 143.2531 & 2812 & 0.050943 & & & & & \\
\hline & Total & 150.016 & 2813 & & & & & & \\
\hline \multirow[t]{3}{*}{ Partner } & Between groups & 0.059069 & 1 & 0.059069 & 0.579488 & 0.4466 & 0.426 & 0.122 & 0.000 \\
\hline & Within groups & 286.636 & 2812 & 0.101933 & & & & & \\
\hline & Total & 286.6951 & 2813 & & & & & & \\
\hline \multirow[t]{3}{*}{ Bank } & Between groups & 1.253802 & 1 & 1.253802 & 5.541509 & $0.018 * *$ & 0.014 & 0.000 & 0.000 \\
\hline & Within groups & 636.233 & 2812 & 0.226256 & & & & & \\
\hline & Total & 637.4869 & 2813 & & & & & & \\
\hline \multirow[t]{3}{*}{ ALMI } & Between groups & 0.084702 & 1 & 0.084702 & 2.197711 & 0.1383 & 0.199 & 0.003 & 0.003 \\
\hline & Within groups & 108.3776 & 2812 & 0.038541 & & & & & \\
\hline & Total & 108.4623 & 2813 & & & & & & \\
\hline \multirow[t]{3}{*}{ Government grants } & Between groups & 0.422119 & 1 & 0.422119 & 4.448888 & 0.35 & 0.060 & 0.004 & 0.000 \\
\hline & Within groups & 266.8078 & 2812 & 0.094882 & & & & & \\
\hline & Total & 267.2299 & 2813 & & & & & & \\
\hline \multirow[t]{3}{*}{ Risk capital com. } & Between groups & 0.001433 & 1 & 0.001433 & 0.184594 & 0.6675 & 0.699 & 0.391 & 0.000 \\
\hline & Within groups & 21.82657 & 2812 & 0.007762 & & & & & \\
\hline & Total & 21.828 & 2813 & & & & & & \\
\hline \multirow[t]{3}{*}{ Angel investors } & Between groups & 0.403704 & 1 & 0.403704 & 27.70886 & $0.000 * *$ & 0.002 & 0.000 & 0.000 \\
\hline & Within groups & 40.96943 & 2812 & 0.014569 & & & & & \\
\hline & Total & 41.37313 & 2813 & & & & & & \\
\hline \multirow[t]{3}{*}{ Other Sources } & Between groups & 0.015495 & 1 & 0.015495 & 0.79407 & 0.3729 & 0.290 & 0.073 & 0.000 \\
\hline & Within groups & 54.87008 & 2812 & 0.019513 & & & & & \\
\hline & Total & 54.88557 & 2813 & & & & & & \\
\hline
\end{tabular}

Note: ${ }^{* *}$ Coefficients are significant at the 0.05 level; Levene statistic, test of homogeneity, at the $0.05 \%$ level; Welch $\mathrm{t}$ test, robust tests of equality of men of groups, and JB $p$-value of means at the $0.05 \%$ level. 
Based on the results of ANOVA above, the aim of next section is to implement four binary logistics, identifying the variables that explain types of financial resources used by firms in the sample.

\section{The Results of Logistic Regression Estimation}

\subsection{Loan from Family Members}

This first model contains all the explanatory variables that determine loans from family members, shown in Table 3. Since the model is a stepwise logistic regression, the variables that were not significant have been removed. Thus, six explanatory variables of a total ten are significant to explain changes in loans from family members. The results demonstrate that ethnicity, experience of starting a business, the amount of personal start-up capital and firm size, affect the dependent variable significantly and positively. On the contrary, the owner's gender and age have a negative and significant influence on the dependent variable. Consequently, female owners, on average, rely more on loans from family members at start-up than the male group. These results provide evidence supporting hypotheses $2,3,4,5,8$ and 9 . As shown by odds ratio (EXP (B)), owners from an ethnic background are 1.6 times more likely to borrow money from a family member at start-up stage than native owners. Likewise, female owners are also 0.5 times more likely to borrow money from family, compared to the male groups. In addition, the odds ratio for ethnicity is the largest, and the odds ratio corresponding to owner age the smallest. Wald's chi-square value for each individual explanatory variable is statistically significant, and confirms their individual contribution to the model. To assess the validity of the results several diagnostic tests are conducted. As the first step, Omnibus and Hosmer $(\chi 2=98.49 ; \mathrm{P}=0.0000)$ and Lemeshow tests $(\chi 2=8.93 ; \mathrm{P}=0.348)$ examine the overall robustness of the model in different ways, confirming that the predictors in the model have a significant effect on the dependent variable. Moreover, since the probability of Wald statistic is less than 0.05 , then the null hypothesis as the variable does not make a significant contribution and can be rejected. As the value associated to classification accuracy prediction rate shows, the model is appropriate since it can distinguish, with $73.8 \%$ accuracy, the group that uses loans from family members from its counterpart. Like R2 in the linear regression model, the Cox and Snell and Nagelkerke R-Square measure the overall explanatory power of the model. The results of these tests show that logistic regression explains approximately $0.03 \%$ per cent of the change in the dependent variable. The Nagelkerke is a modification of Cox and Snell tests, can range from 0 to 1, and is a more reliable measure of the relationship. Nagelkerke's R2 is, in general, higher than the Cox and Snell measure. In this case, it is $0.05 \%$, indicating a weak relationship of variation between the predictors and the dependent variable. The initial -2 log likelihood value for the model decreased after adding the eight predictive independent variables, implying the accuracy of the model.

\subsection{Loan from Friends}

This second model includes ethnicity, owner's age and firm size. The estimated logistic regression results, on the linkages between explanatory variables and loans from friends, are presented in Table 5. Similar to the previous model, and consistent with hypotheses 2, 4 and 9, the ethnicity and firm size influence the loan from friends significantly and positively, whilst the impact of age on it is negative. The odds ratio $(\operatorname{Exp}(\beta))$ of ethnicity indicates that given all other predictors are constant, immigrant owners were nearly 5.7 times more likely to finance their firms by loans from friends than native owners. Thus, this predictor has the largest effect on the dependent variable. In addition, an acceptable overall model fit is supported by significant Omnibus and Hosmer $(\chi 2=102.8 ; \mathrm{P}=0.000)$ and Lemeshow tests $(\chi 2=10.9 ; \mathrm{P}=0.348)$. The accuracy prediction rate of the model is very high and classifies around $94 \%$ of the differences between the two groups correctly; the user of loans from friends and its counterpart. 
Table 5. Results of the third and fourth stepwise logistic regression analyses: dependent variables, loans from family members and loans from friends

\begin{tabular}{|c|c|c|c|c|c|c|}
\hline Loans from family members & $\mathrm{B}$ & S.E. & Wald & $\mathrm{Df}$ & Sig. & $\operatorname{Exp}(B)$ \\
\hline Ethnicity & 0.5111145 & 0.1312565 & 15.163339 & 1 & 0.0001 & 1.6671482 \\
\hline Gender & -0.580711 & 0.0941948 & 38.007255 & 1 & 0.0000 & 0.5595003 \\
\hline Owner age & -1.034554 & 0.3460106 & 8.9397895 & 1 & 0.0028 & 0.355385 \\
\hline Experience & 0.2851275 & 0.0999877 & 8.1317649 & 1 & 0.0043 & 1.3299316 \\
\hline Start-up capital & 0.1007453 & 0.0226441 & 19.794304 & 1 & 0.0000 & 1.1059949 \\
\hline Firm size & 0.2567335 & 0.1200722 & 4.5717298 & 1 & 0.0325 & 1.2927006 \\
\hline \multirow[t]{2}{*}{ Constant } & 0.0994842 & 0.6825401 & 0.0212448 & 1 & 0.8841 & 1.104601 \\
\hline & Chi-square & $\mathrm{Df}$ & Sig. & & & \\
\hline Omnibus tests & 98.493623 & 6 & 0.0000 & \multicolumn{2}{|c|}{ Classification accuracy } & 73.850054 \\
\hline Hosmer and Lemeshow test & 8.9305857 & 8 & 0.3482 & \multicolumn{2}{|c|}{ Cox and Snell tests } & 0.0350444 \\
\hline Wald & 571.57799 & 1 & 0.0000 & \multicolumn{2}{|c|}{ Nagelkerke R squared } & 0.0512646 \\
\hline-2 Log likelihood & & \multicolumn{2}{|l|}{3078.700} & \multicolumn{3}{|c|}{ Heteroskedasticity test: 0.0000} \\
\hline Loan from friends & B & S.E. & Wald & $\mathrm{Df}$ & Sig. & $\operatorname{Exp}(B)$ \\
\hline Ethnicity & 1.7533475 & 0.1797285 & 95.170392 & 1 & 0.0000 & 5.7738984 \\
\hline Owner age & -2.287381 & 0.6435864 & 12.631743 & 1 & 0.0004 & 0.101532 \\
\hline Firm size & 0.4562243 & 0.1673492 & 7.4320608 & 1 & 0.0064 & 1.5781042 \\
\hline \multirow[t]{2}{*}{ Constant } & -1.399546 & 1.0430388 & 1.8004187 & 1 & 0.1797 & 0.2467089 \\
\hline & Chi-square & Df & Sig. & & & \\
\hline Omnibus tests & 102.83196 & 3 & 0.0000 & \multicolumn{2}{|c|}{ Classification accuracy } & 94.349873 \\
\hline Hosmer and Lemeshow test & 10.930436 & 8 & 0.2057 & \multicolumn{2}{|c|}{ Cox and Snell tests } & 0.0365594 \\
\hline Wald & 1166.6086 & 1 & 0.0000 & \multicolumn{2}{|c|}{ Nagelkerke R squared } & 0.1037483 \\
\hline-2 Log likelihood & & 1096.713 & & \multicolumn{3}{|c|}{ Heteroskedasticity test: 0.0000} \\
\hline
\end{tabular}

The coefficients are all significant at the 0.05 level, potential heteroskedasticity was examined using the Breusch-Pagan/Cook-Weisberg test, confirming that models are correctly specified.

As shown by Cox and Snell and Nagelkerke R-Squares, around $0.036 \%$ and $0.10 \%$, respectively, of the variation in the dependent variable is explained by the logistic model.

\subsection{Bank Loans}

As shown in Table 6, it is clear that eight of the ten tested variables are statistically significant to explain the change in the bank loan dependent variable. Whereas the impacts of ethnicity and industry affiliation on bank loans are negative, all other predictors have the opposite effect. This means that owners from an ethnic background tend to use less loans from banks compared to native owners. Moreover, firms operating in the less developed service industries are also less likely to uses bank loans. These findings imply that the results uphold all hypotheses, with the expectation of hypotheses 3 and 4. Both the Omnibus and Hosmer and Lemeshow tests of the model are found to be statistically significant. The classification accuracy rate of the model is relatively high differentiating correctly $73.8 \%$ of the two groups that use loans from bank and the firms which do not use them. 
Table 6. Results of the third and fourth stepwise logistic regression analysis: dependent variables, bank loans and funding by angel investors

\begin{tabular}{|c|c|c|c|c|c|c|}
\hline Bank loans & $\mathrm{B}$ & S.E. & Wald & Df & Sig. & $\operatorname{Exp}(B)$ \\
\hline Ethnicity & -0.425 & 0.1412 & 8.86337755 & 1 & 0.0029 & 0.6569 \\
\hline Experience before & 0.3127 & 0.0915 & 11.6677325 & 1 & 0.0006 & 1.3671 \\
\hline Additional job & 0.269 & 0.0872 & 9.52084877 & 1 & 0.0020 & 1.3086 \\
\hline University education & 0.2232 & 0.1017 & 4.81227986 & 1 & 0.0283 & 1.25 \\
\hline Start-up capital & 0.0674 & 0.0208 & 10.5181149 & 1 & 0.0012 & 1.0697 \\
\hline Firm size & 1.0975 & 0.1636 & 45.0324262 & 1 & 0.0000 & 2.9968 \\
\hline Legal form & 0.0148 & 0.0029 & 26.2514984 & 1 & 0.0000 & 1.0149 \\
\hline Industry & -0.024 & 0.0101 & 5.51430056 & 1 & 0.0189 & 0.9765 \\
\hline \multirow[t]{2}{*}{ Constant } & -2.207 & 0.3431 & 41.3755639 & 1 & 0.0000 & 0.1101 \\
\hline & Chi-square & $\mathrm{Df}$ & Sig. & & & \\
\hline Omnibus tests & 207.71 & 8 & 0.0000 & \multicolumn{2}{|c|}{ Classification accuracy } & 67.657 \\
\hline Hosmer and Lemeshow test & 30.357 & 8 & 0.0002 & \multicolumn{2}{|c|}{ Cox and Snell tests } & 0.0725 \\
\hline Wald & 250.16 & 1 & 0.0000 & \multicolumn{2}{|c|}{ Nagelkerke R squared } & 0.1 \\
\hline-2 Log likelihood & & \multicolumn{2}{|c|}{$3357.042 \mathrm{a}$} & \multicolumn{3}{|c|}{ Heteroskedasticity test: 0.000} \\
\hline Angel investors & $\mathrm{B}$ & S.E. & Wald & Df & Sig. & $\operatorname{Exp}(B)$ \\
\hline Ethnicity & 1.5433 & 0.3322 & 21.5849 & 1 & 0.0000 & 4.6823 \\
\hline Owner age & -3.45 & 1.2092 & 8.1383 & 1 & 0.0043 & 0.0318 \\
\hline Firm size & 0.6181 & 0.2272 & 7.4039 & 1 & 0.0065 & 1.8555 \\
\hline \multirow[t]{2}{*}{ Constant } & -0.775 & 1.9381 & 0.1601 & 1 & 0.6891 & 0.4605 \\
\hline & Chi-square & $\mathrm{Df}$ & Sig. & & & \\
\hline Omnibus tests & 31.749 & 3 & 0.0000 & \multicolumn{2}{|c|}{ Classification accuracy } & 98.515 \\
\hline Hosmer and Lemeshow 9.42280 .308 & & & & \multicolumn{2}{|c|}{ Cox and Snell tests } & 0.0114 \\
\hline Wald & 710.74 & 1 & 0.0000 & \multirow{2}{*}{\multicolumn{2}{|c|}{ Nagelkerke R squared }} & 0.0799 \\
\hline -2 Log likelihood & & 394.840 & & & & \\
\hline
\end{tabular}

All coefficients are significant at the 0.05 level, potential heteroskedasticity was examined using the Breusch-Pagan/Cook-Weisberg test, confirming that models are correctly specified.

\subsection{Funding by Angel Investors}

It can be noted from Table 6 that three explanatory variables - ethnicity, owner's age and firm size - have significant effects on the dependent variable, funding by angel investors. As was the case in the second model, both ethnicity and size impact the funding by angel investors positively, while the owner's age negatively influences it. These results support hypotheses 2, 3 and 9. Both Omnibus and Lemeshow tests yield a chi-square statistic of $(\chi 2=31.7 ; \mathrm{P}=0.000)$ and $(\chi 2=9.4 ; \mathrm{P}=0.308)$, respectively, which is significant, suggesting that the model fits the data in the sense that at least one independent variable has an effect on the dependent variable. The validity tests, including Wald and -2 Log likelihood test, also provide an overall indication of how well the model has performed. In addition, while the value corresponding to the classification accuracy prediction rate is extremely high, both Cox and Snell and Nagelkerke R squared are at a low level, 0.0114 and 0.0799, respectively.

To sum up, by way of comparison with previous studies it can be noted that Swedish small native and immigrant-owned firms at start-up stage are distinguished with regard to the use of just four financing sources: loans from family, friends, banks and angel investors. However, while the impact of the owner's ethnicity is negative on loans from bank, it has a positive influence on loans from family and friends, and funding by angel investors. Moreover, the impact of the owner's ethnicity, measured in Exp (B), is largest on loans from friends and smallest on loans from banks. However, the gender of owners only affects loans from family members.

The owner's age is another important variable which influences all funding sources negatively, expect bank loans. Older owners are less likely to use loans from family, friends and funding by angel investors compared to the younger owners. Size (number of employees) impacts all funding sources positively. Other variables, such as owner's prior experience of starting a business, and the amount of the funder's personal capital are important predictors of loans from family members. Interestingly, both personal characteristics, such as prior experience of starting a business, additional job beside the own business, and educational level, as well as firm characteristics, such as firm size, legal form and industry affiliation, have an impact on loans from banks. 


\section{Concluding Remarks}

The present study investigates whether characteristics of owners and firms influence finance-seeking behaviour among Swedish small owned firms at start-up stage. The empirical results point to striking differences between native and immigrant-owned firms, with regard to the use of four financing sources: loans from family members, friends, banks, and use of funding obtained from angel investors. The findings confirm that ethnicity, gender and age are significant to distinguish between native and immigrant-owned firm loans from family members. However, despite ethnicity's impact on loans from friends and banks, and the use of funding obtained from angel investors, gender has no significant influence on them. This finding suggests also that other personal characteristics, such as age, prior experience of starting a business, and educational level, as well as firm characteristics, such as firm size, legal form and industry affiliation, have a partial effect on other financial sources.

The study contributes to a better understanding of the role of ethnicity and gender, age, prior experience in business, education, having an additional job beside one's own business, the amount of personal start-up capital and firm size, as well as legal form and industry affiliation.

on the financing behaviour of small business at start-up stage, which can be used by many firm stakeholders, including managers, policymakers and banks, as well as potential investors, in facilitating the use of external conventional financial sources by small businesses at start-up.

\section{References}

Basu, A., \& Parker, S. C. (2001). Family finance and new business start-ups. Oxford Bulletin of Economics and Statistics, 63(3), 333-358. http://dx.doi.org/10.1111/1468-0084.00224

Bellucci, A., Borisov, V. A., \& Zazzaro, A. (2009). Does gender matter in bank-firm relationships? Evidence from small business lending. Journal of Banking and Finance, 34(12), 2968-2984. http://dx.doi.org/10.1016/j.jbankfin.2010.07.008

Blanchflower, D., Levin, P. B., \& Zimmerman, D. J. (2003). Discrimination in the small- business credit market. The Review of Economics and Statistics, 85(4), 930-943. http://dx.doi.org/10.1162/003465303772815835

Brophy, D. (1989). Financing women owned entrepreneurial firms. In Hagan, O., Rivchun, C., \& Sexton, D. (Eds.), Women Owned Businesses (pp. 55-76). New York: Praegar.

Bruder, J., Neuberger, D., \& Döppner, S. R. (2011). Financial constraints of ethnic entrepreneurship: evidence from Germany. International Journal of Entrepreneurial Behaviour and Research, 17(3), 296-313. http://dx.doi.org/10.1108/13552551111130727

Brush, C. (1992). Research on women business owners: past trends, a new perspective and future directions. Entrepreneurship Theory and Practice, 16(1), 5-30.

Brush, C. G., Carter, N. M., Gatewood, E. J., Greene, P. G., \& Hart, M. M. (2006). Introduction: The Diana Project international. In Brush, C. G., Carter, N. M., Gatewood, E. J., Greene, P. G., \& Hart, M. M. (Eds), Growth-Oriented Women Entrepreneurs and their Businesses: A Global Perspective (pp. 3-22). Cheltenham: Edward Elgar.

Carter, N. M., \& Allen, K. R. (1997). Size determinants of women-owned businesses: choice or barriers to resources? Entrepreneurship and Regional Development, 9(3), 211-220. http://dx.doi.org/10.1080/08985629700000012

Carter, S., \& Rosa, P. (1998). The financing of male- and female-owned businesses. Entrepreneurship and Regional Development, 10(3), 225-241. http://dx.doi.org/10.1080/08985629800000013

Cavalluzzo, K. S., Cavalluzzo, L. C., \& Wolken, J. D. (2002). Small business financing, and discrimination: evidence from a new survey. The Journal of Business, 75(4), 641-679. http://dx.doi.org/10.1086/341638

Cobb-Clarck, D., \& Hildebrand, V. (2002). The wealth and Asset Holdings of US and Foreign Born Households: Evidence from SIPP data. Discussion Paper 674 from the Institute for the study of Labor: Bonn, Germany. December 2002. Available may 2012 at: www.iza.org

Coleman, S. (1998). Access to capital: a comparison of men and women-owned small businesses. Paper presented at The Babson-Kauffman Entrepreneurship Research Conference, 21 May, Gent: Belgium.

Davidson, M. J., Fielden, S. L., \& Omar, A. (2010). Black, Asian and Minority Ethnic female business owners: Discrimination and social support. International Journal of Entrepreneurial Behaviour and Research, 16(1), 58-80. http://dx.doi.org/10.1108/13552551011020072 
Devine, T. J. (1994). Characteristics of self-employed women in the United States. Monthly Labour Review, $117(3), 20-34$.

Essers, C., \& Benschop, Y. (2007). Enterprising identities: female entrepreneurs of Moroccan and Turkish origin in The Netherlands. Organization Studies, 28(1), 49-69. http://dx.doi.org/10.1177/0170840607068256

Fay, M., \& Williams, L. (1993). Gender bias and the availability of business loans. Journal of Business Venturing, 8(4), 363-377. http://dx.doi.org/10.1016/0883-9026(93)90005-P

Fischer, E., Reuber, R., \& Dyke, L. (1993). A theoretical overview and extension of research on sex, gender, and entrepreneurship. Journal of Business Venturing, 8(2), 151-168. http://dx.doi.org/10.1016/0883-9026(93)90017-Y

Guiso, L., \& Rustichini, A. (2011). What drives women out of entrepreneurship? The joint role of testosterone and culture. Working Paper 2, European University Institute, Department of Economics. Florence:Italy January 4, 2011.

Hedberg, C. (2009). Intersections of Immigrant Status and Gender in the Swedish Entrepreneurial Landscape. Working Paper 8, The Stockholm University, Linnaeus Center for Integration Studies (SULCIS), Stockholm: Sweden.

Huang, J., \& Kisgen, D. J. (2008). Gender and corporate finance. Paper presented at USC FBE Finance Seminar, October 3, Los Angeles, CA. Page nos 50. Available May 2012 at http://documents.im/pdf/1/gender-and-corporate-finance.html

Huck, P., Rhine, S., Bond, P., \& Townsend, R. (1999). Small business finance in two Chicago Minority neighbourhoods. Economic Perspectives, 2, 46-62.

Hussain, J., Matlay, H., \& Scott, J. (2008). Financial education in small ethnic minority businesses in the UK. Education and Training, 50(8/9), 737-747. http://dx.doi.org/10.1108/00400910810917109

Irwin, D., \& Scott, J. M. (2010). Barriers faced by SMEs in raising bank finance. International Journal of Entrepreneurial Behaviour and Research, 16(3), 245-259. http://dx.doi.org/10.1108/13552551011042816

Kalleberg, A. L., \& Leicht, K. T. (1991). Gender and Organizational Performance: Determinants of Small Business Survival and Success. Academy of Management Journal, 34(1), 136-161. http://dx.doi.org/10.2307/256305

Kloosterman, R. (2003). Creating opportunities. Policies aimed at increasing openings for immigrant entrepreneurs in the Netherlands. Entrepreneurship and Regional Development, 15(2), 167-181. http://dx.doi.org/10.1080/0898562032000075159

Kushnirovich, N., \& Heilbrunn, S. (2008). Financial funding of Immigrant businesses. Journal Developmental Entrepreneurship, 13(2), 167-184. http://dx.doi.org/10.1142/S1084946708000910

Lo, L., Teixeira, C., \& Truelove, M. (2002). Cultural resources, ethnic strategies and immigrant entrepreneurship: a comparative study of five ethnic groups in the Toronto CMA. Working Paper No. 21, School of Applied Geography, Ryerson University, Toronto, Ontario: Canada, November 2002.

Maltay, H., Scott, M., \& Whittam, G. (2011). Ethnic entrepreneurship in reverse in the UK: Is there gender bias in access to finance for South Asian women entrepreneurs? Paper presented at The $56^{\text {th }}$ Annual ISCB World Conference, 15-18 June 2011, Stockholm: Sweden.

Marlow, S., \& Carter, S. (2006). If you don't ask you don't get! Women, self-employment and finance. Paper presented to Warwick Business School Small Firms Finance Conference, May, Coventry: UK.

Muravyev, A., Schäfer, D., \& Talavera, O. (2007). Entrepreneurs' gender and financial constraints: Evidence from international data. Working paper from German Institute for Economic Research (DIW) and European University Institute. July 16, 2007: Berlin: Germany.

Osili, U. O., \& Paulsson, A. (2004). Prospects of immigrant-native wealth assimilation: evidence from financial market participation. Working Paper series 04-18. Federal Reserve Bank of Chicago: Chicago, USA.

Papadaki, E., \& Chami, B. (2002). Growth Determinats of Micro-businesses in Canada. Small Business Policy Branch Industry, Canada.

Raijman, R., \& Tienda, M. (2003). Ethnic foundations of economic transactions: Mexican and Korean immigrant entrepreneurs in Chicago. Ethnic and Racial Studies, 26(5), 783-801. http://dx.doi.org/10.1080/0141987032000109032 
Ram, M., Smallbone, D., Deakins, D., \& Jones, T. (2003). Banking on break out: finance and the development of ethnic minority businesses. Journal of Ethnic and Migration Studies, 29(4), 663-681. http://dx.doi.org/10.1080/1369183032000123440

Ram, M., Theodorakopoulos, N., \& Jones, T. (2008). Forms of capital, mixed embeddedness and Somali enterprise. Work, Employment and Society, 22(3), 427-446. http://dx.doi.org/10.1177/0950017008093479

Ramangalahy, C., Brenner, G. A., Menzies, T. V., \& Filion, L. J. (2002). Ethnic enterprise start up stage: an empirical survey among the Chinese, Italian and Sikh entrepreneurial communities. Working Paper No. 15, September. Presented at McGill Conference on International Entrepreneurship: Researching New Frontiers, September 13 to 16 2002, McGill University, Montreal: Canada.

Robb, A., \& Wolken, J. D. (2002). Firm, owner, and financing characteristics: differences between female- and male-owned small businesses. Federal Reserve System Research Paper Series - FEDS Papers, Working paper No. 18, March. Page nos: 28. Washington: USA.

Schrover, M., Van Der Leun, J., \& Quispel, C. (2007). Niches, labour market segregation, ethnicity and gender. Journal of Ethnic and Migration Studies, 33, 529-540. http://dx.doi.org/10.1080/13691830701265404

Shanmuganthan, P., Spinder, D., Stone, M., \& Foss, B. (2003) Does ethnic focus change how banks should implement customer relationship management? Journal of Financial Services Marketing, 8(1), 49-62. http://dx.doi.org/10.1057/palgrave.fsm.4770106

Smallbone, D., Bertotti, M., \& Ekanem, I. (2005). Diversification in ethnic minority business: the case of Asians in London's creative industries. Journal of Small Business and Enterprise Development, 12(1), 41-56. http://dx.doi.org/10.1108/14626000510579635

Smallbone, D., Ram, M., Deakins, D., \& Baldock, R. (2003). Access to finance from ethnicminority businesses: some results from a national study. International Small Business Journal, 21(3), 287-308.

Smart, J. (2003). Ethnic entrepreneurship, transmigration, and social integration: an ethnographic study of Chinese restaurant owners in rural Western Canada. Urban Anthropology and Studies of Cultural Systems and World Economic Development, 32(3/4), 311-342.

Srinivasan, S. (1995). The South Asian Petty Bourgeoisie in Britain: An Oxford Case Study. Research in Ethnic Relations Series. Avebury, Aldershot:UK

Verheul, I., \& Thurik, R. (2001). Start-up capital: does gender matter? Small Business Economics, 16(4), 329-346. http://dx.doi.org/10.1023/A:1011178629240

Verheul, I., van Stel, A., \& Thurik, R. (2004). Explaining female and male entrepreneurship across 29 countries. Discussion Paper $n r 0804$ on Entrepreneurship, Growth and Public Policy. Max Planck Institutet for Research into Economic Systems Group Entreprenership, Growth and Public Policy, Jena: Germany, p. 32.

Werbner, P. (1990). Renewing an industrial past: British Pakistani entrepreneurship in Manchester. A European Journal of International Migration and Ethnic Relations, 8(7), 17-41. 